\title{
Straight Separatism: Ten Theses on the Queer Archive
}

Stanimir Panayotov

Central European University, Budapest

This text is a revised version of a paper presented at the conference In/visible: The Sexual and Political Regimes of the Archive, in a panel titled "The Queer Location of Culture: Nationalism, History, Sexuality" (Skopje, National Gallery of Macedonia - Chifte Hamam, 25 February 2012).

Definition: Straight separatism is the culture of self-assimilation in the forms of institutionality and memorialization.

Thesis 1: All culture is the archive of heterosexuality and identity, because they imply each other. The battle for remembrance is the battle for the recognition of exclusionary identity and not of the excluded one. All culture is about the political self-determination of one identity - the straight one - against the organized self-destruction of all others. Queers exist through the death drive. The institution of the archive is the alleviation of that drive.

Theses 2: Since society is today fragmented down to culturalized bits of identities and a politics of identitarian totalitarianism, all society and institutions - including the museum are camps of erotically decorated straight separatism. The forms of formalizing memory are separatist strategies of straight survival. The queer archive is a huge dark thanatological and eschatological abyss of desires, the formalization of which does not reform the false universality of straight separatism. Queer inclusion is the ghettoization of the question of difference within the biopolitical camp of straightness. One has to either change the form of institution or abandon recollection altogether.

Thesis 3: The form of institution, apart from being a biopolitical site of exclusion, is the battlefield of identity. Since identity in and of itself is heterosexual, the very form of institution is a straight ghetto. However, the battle is on the ground of the straight imaginary and the straight body. The question of remembrance is not the question of exclusion; rather, the 
question is: do we, queers, want to mummify ourselves in identity: a form of transhistorical survivalism that has been designed for mythomanic heterosexuals?

Thesis 4: The institution is the reproduction of (straight) identity. As such, it is the selfenclosure which says "not you". Insofar as this form is straight, and insofar as identity is the formalization of heterosexuality, the institution is a sociocultural ghetto of heterosexuality. The desire of queers for self-archiving and identitization is an inverted form of straight sadism. To invade the straight ghetto is not to prove human universality, but to join the spoils of particularity and false consciousness.

Thesis 5: The inclusion of queers in the very form of institution is not a step towards universality: it is to succumb to the imperative of recognition. Just as the question of gay marriage involves the mere right to marry, and not the obligation to, just as we want to be part of an already corroded history of universality - marriage - which is buttressed by its violent past, so the inclusion of the queer archive under the institutional panoply is no more than the desire for diversification of the very form of institutional oppression in history - the ghetto of exclusion.

Thesis 6: The creation of (and queering the form of) institution is an act of nihilism, selfcontempt and yet another converted form of socially imposed self-destruction. Therefore, the making of the queer archive should be done by straight separatists - that is, the society of the identitarian-fascist form of institution, It is only by relegating this work to straights that we can continue the enjoyment of our anomic desires, for all desire is anomic. If straight separatists are not able to face and declare their particularity through the repressive paradigm of recognition (which is their only way to performatively experience the exclusions perpetrated), we cannot change the course of history and remembrance.

Thesis 7: The queer memory and archive are immanent; they embody immanent materiality (or: communal-telepathic transmission of the histories of love). Unlike the straight separatism of the form of institution with its identity-fascism, the queer archive is the practice of everyday life. The excluded artifacts of sexual difference are on display in the collective memories of our entangled bodies and their stories of fucking, love, affection. Our memories are our museums. 
Thesis 8: The formalization of remembrance and memory of sexual difference cannot be non-normative. What binds all such attempts, queer and straight alike, is the failure of a common universality and a common social project. The most we can hope for is to convert the inherent antisociality between us into the politics of successful miscommunication.

Thesis 9: The only queer archive we can make ourselves without it being appropriated by a false universalism and straight separatism is our transgression of the paradigm of love and the paradigm of recognition. The only way to change the formalization of memory and to counter forgetfulness is to abandon the paradigm of recognition. Leave it to the queer-straight bureaucrats to remember.

Thesis 10: The making of the queer archive is merely the exposure of false consciousness: both the one of pseudo-universal heterosexuality and assimilated queerness. The only change and difference we can make is (1) expose both the institution and identity-fascism as false consciousness, and thus (2) either join the rewriting of straight separatism into a collective one (3) or else abandon all forms of remembrance. 